\title{
Development of Verification System of Earthwork Amount using 3D Analysis Cell
}

\author{
Jae-Woo Park ${ }^{\mathrm{a}}$, Seok Kim ${ }^{\mathrm{b} *}$ \\ ${ }^{a}$ Korea Institute of Construction Technology, Goyang-daero, Goyang-si, Gyeonggi-do, 10223, Rep. of Korea \\ ${ }^{b}$ Korea National University of Transportation, 157 Cheoldobangmulgwan-ro, Uiwang-si, Gyeonggi-do, 16106, Republic of Korea
}

\begin{abstract}
The Efforts has been made with a fast speed to the automation of earthworks focused on global construction machinery enterprises. By using drone or terrestrial laser scanner, the work site can be measured rapidly and by using this it aims to provide various solutions to operate construction machinery effectively. In order to manage effectively the process of construction, it is important to figure out the changes of amount of earth cutting and banking with respective work site upon measuring the total volume of work in the progress of the project. In this study, the Analysis Cell introduced in earlier research is applied to the real work site to analyse the amount of work, cutting and banking. Applying to test bed, the amount of cutting and banking in the early stage were identified to have been decreased gradually in connection with the progress of works. Furthermore, based on Analysis Cell, it could be verified that work site has been changed to the similar shape of the design drawing.
\end{abstract}

(C) 2018 The Authors. Published by Diamond Congress Ltd., Budapest University of Technology and Economics Peer-review under responsibility of the scientific committee of the Creative Construction Conference 2018.

Keywords: terrestrial laser scanner, analysis cell, earthwork amount, verification system ;

\section{Introduction}

The Effort has been made with fast pace to automate the earthwork construction focused on the global construction equipment enterprises such as Caterpillar and Komatsu. By using drone or TLS(terrestrial laser scanner), the work site can be measured rapidly and by using this, it aims to provide various solutions to operate construction machinery effectively. Such efforts by the global construction companies are expected to lead to an ultimate change in the work style of the construction industries. [1].

Currently, the equipment operating system is being developed to be focused on the efficient operation of the equipment by the global construction machinery enterprises; however, there is still an insufficient part to be applied to the construction work site. It is because the purpose of the construction industry is focusing on the effectiveness of process management, not on the efficient operation of equipment. In order to manage effectively the process of construction, it is important to figure out the changes of amount of earth cutting and banking with respective work site upon measuring the total volume of work in the progress of the project. The site manager establishes the work management schedule to perform effectively construction projects based on the management information.

D. Lee et al [2] proposed a methodology to manage the site using the Analysis Cell. In this study, the work site is split into 3D dimension and then the earth volume by respective Analysis Cell is examined. This study analyzes the amount of earthwork volume, cutting and banking, by applying the Analysis Cell to real work site. 


\section{Creation of 3D Analysis Cell}

It is necessary to establish the plan on how to operate the construction machinery of an excavator, a wheel loader, and a truck, etc. to perform earthwork efficiently. In order to do that, we should know the amount of earthwork and location information. D. Lee et al [2] presented the concept of three-dimensional Analysis Cell having the information to perform the earth work efficiently as illustrated in Fig.1.

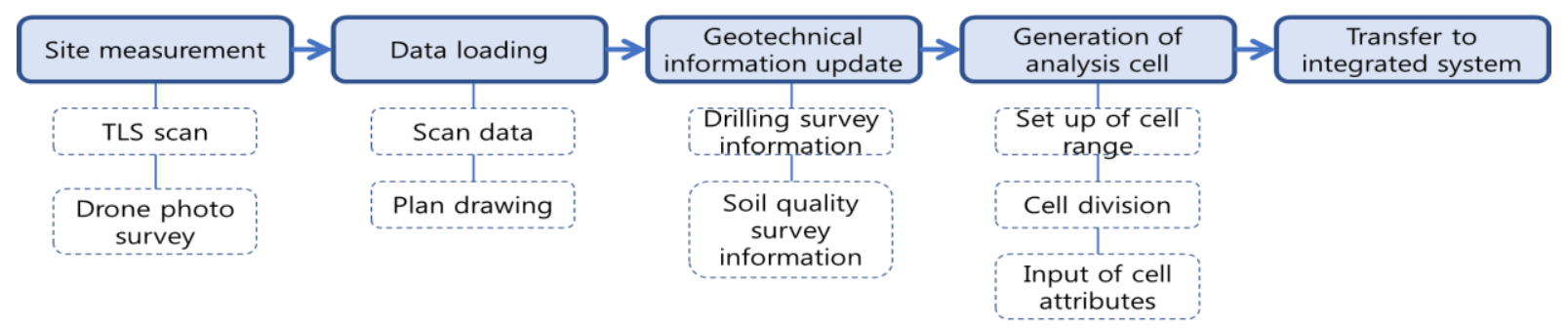

Fig. 1. Process of the 3D geotechnical analysis platform (referred from [1])

First, the site is scanned using the terrestrial laser scanner (TLS) and the site is measured using a drone. The site data (point cloud) measured by the TLS and the drone and the design drawing are imported. The drilling survey information and the soil quality survey information is updated in the imported data. At that point, the range of earthwork is established and the three-dimensional Analysis Cell is created. The Analysis Cell has the information on the amount of earthwork and the property of soil, etc. The changes in the amount of earthwork, cutting and banking. can be evaluated using the Analysis Cell according to the construction progress.

\section{Case Study}

The performance has been verified by applying the developed Analysis Cell system in the test bed of earthwork. The experiment was realized in December, 2017, the analysis was implemented by targeting the earthwork over a 4 days period. The experiment location was in empty ground located in Ansan City, Gyeonggi-do, Republic of Korea. Fig. 2 is the aerial view of the work site that the experiment was being realized. The cutting and banking are signified at point $A$, and point $B$ signifies the spoil area.

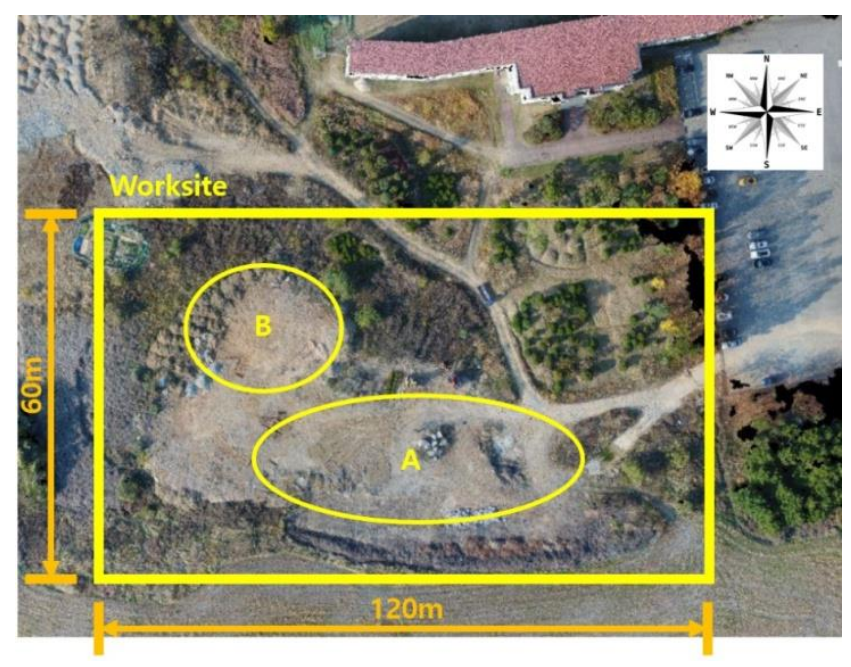

Fig. 2. The aerial view of work site 
Based on the data scanned from real work site and the design drawing, the initial Analysis Cell has been created as shown in Fig.3. The Analysis Cell includes the information of amount of earthwork, cutting and banking, evaluated by comparing the design drawing and the real work site. The amount of cutting and banking can be calculated for the construction work site based on the information of each Analysis Cell. The construction manager is able to establish the operation plan for the construction machinery based on the analyzed total amount of earthwork.

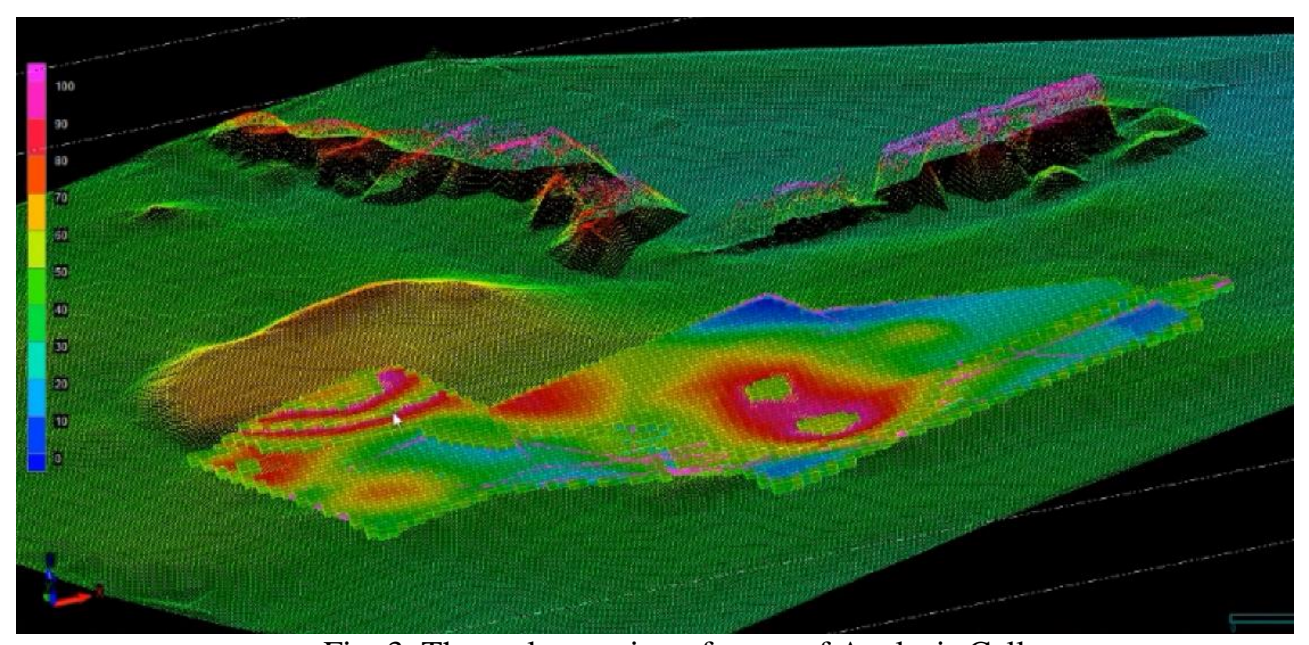

Fig. 3. The early creation of stage of Analysis Cell

Changes occur in the topography of work site through the earthwork over four days. The work progressed, so that it may be the same type as the design drawing, and sand was transported from the location that cutting was necessary to the location that banking was necessary. The earthwork was performed by utilizing two excavators, one truck, and one dozer in the test bed. The cutting and banking work performed focused on the area $\mathrm{A}$ in the $1^{\text {st }}$ and the $2^{\text {nd }}$ day. The work in the spoiled area at point B area occurred on the $3^{\text {rd }}$ and $4^{\text {th }}$ day.

Fig. 4 shows the changes in the amount of work by the number of work days. The red colored territory in the figure is the point where cutting or banking is necessary in relation to the real topography compared with the design drawing. The blue colored territory is the point where there is no significant difference between the design drawing. The blue colored Analysis Cell similar to the territory with the design drawing can be identified as the total work which progressed from the $1^{\text {st }}$ day to the $4^{\text {th }}$ day. On the contrary, the red colored territory decreases gradually.

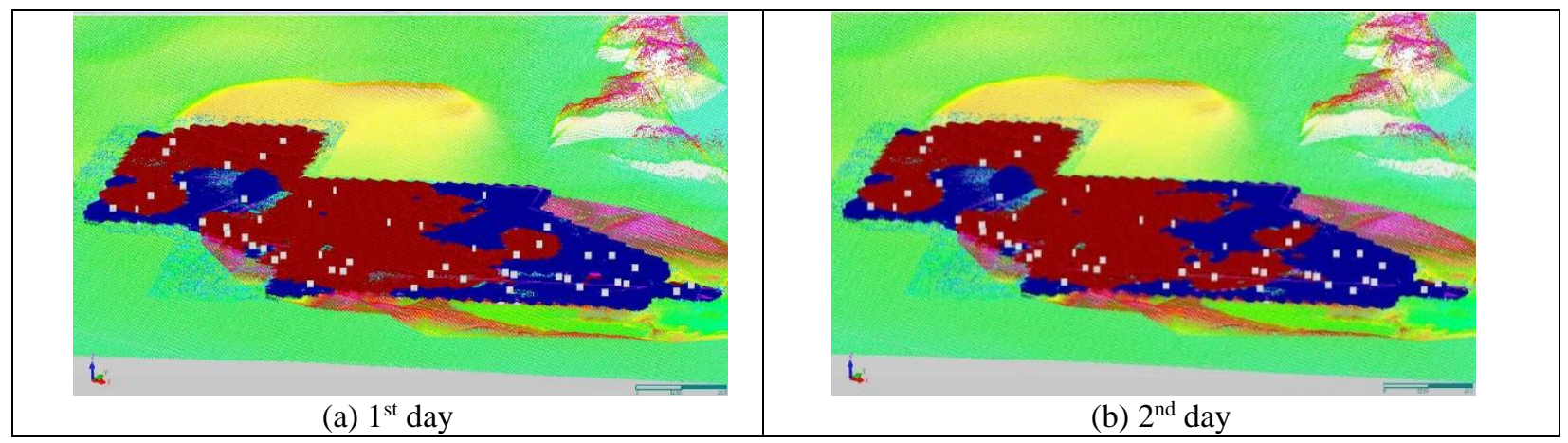




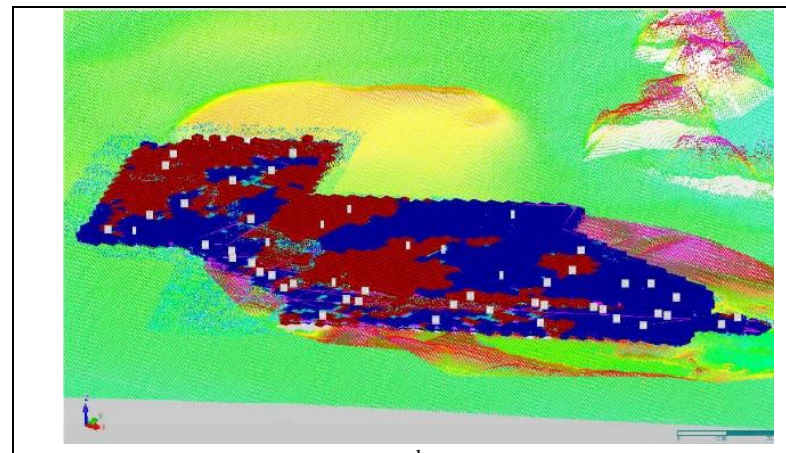

(c) $3^{\text {rd }}$ day

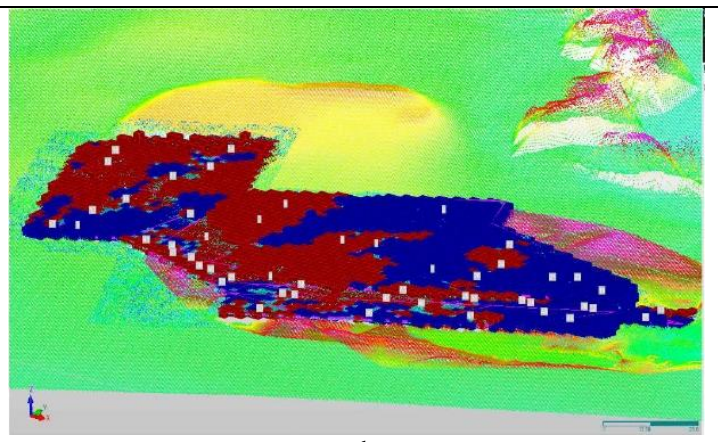

(d) $4^{\text {th }}$ day

Fig. 4. The change for the amount of work

Fig. 5 shows the changes in the amount of cutting and banking. The blue colored territory is the region where the banking is necessary, and the red colored territory is the region where cutting is necessary. The blue colored territory located on the left side decreased as the work progressed; the red colored territory that occurred at point of B was used as the temporary spoil area.

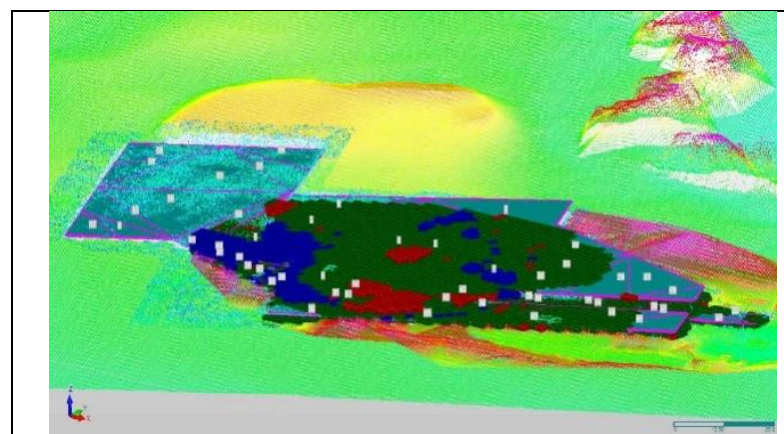

(a) $1^{\text {st }}$ day

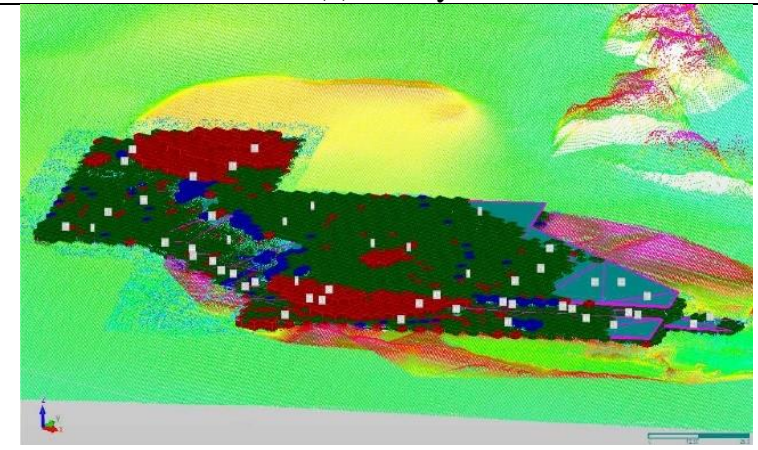

(c) $3^{\text {rd }}$ day

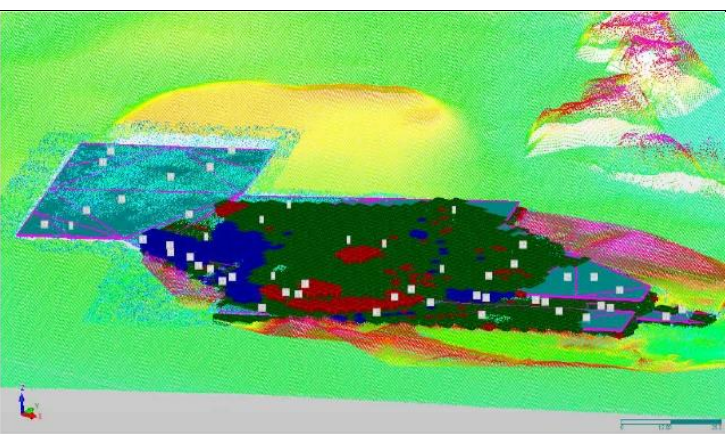

(b) $2^{\text {nd }}$ day

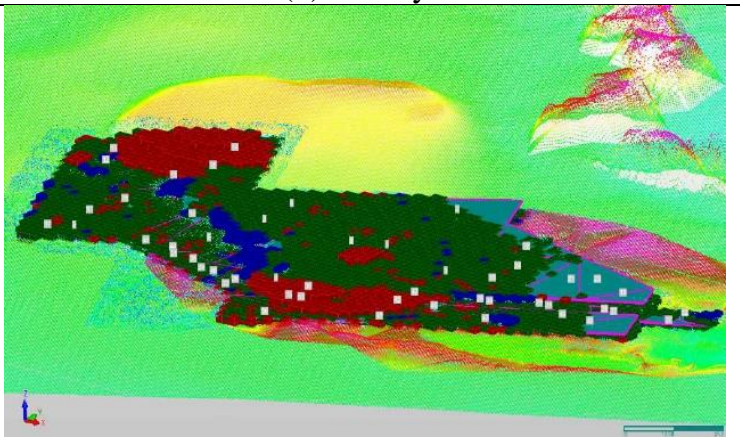

(d) $4^{\text {th }}$ day

Fig. 5. The change of the amount of cutting and banking

Table 1 is the change of Analysis Cell arranged for the 4-day period. 4,263 units of Analysis Cell were created based on the plan drawing and the scanned data of site in the initial stage, the total amount of cutting was analyzed as $3,177 \mathrm{~m}^{3}$, and the total amount of banking was analyzed as $2,806 \mathrm{~m}^{3}$. From that point, Analysis Cell with the cutting and the adding Analysis Cell with the banking disappeared as the earthwork progressed. Besides, the amount of cutting and banking that each cell has changed as the work progressed. was noted that the number of Analysis Cell were being decreased, and the amount of cutting and banking is being decreased as the work is progressed by $4^{\text {th }}$ day.

Table 1. Analysis result

\begin{tabular}{|l|c|c|c|c|c|c|} 
Number & The number & Added cell & Deleted cell & Changed cell & The amount & The amount \\
\hline
\end{tabular}




\begin{tabular}{|c|c|c|c|c|c|c|}
\hline $\begin{array}{c}\text { scanned } \\
\text { times }\end{array}$ & $\begin{array}{c}\text { of Analysis } \\
\text { Cell }\end{array}$ & & & & $\begin{array}{c}\text { of cutting } \\
\left(\mathrm{m}^{3}\right)\end{array}$ & $\begin{array}{c}\text { of banking } \\
\left(\mathrm{m}^{3}\right)\end{array}$ \\
\hline initial stage & 4263 & 0 & 0 & 0 & 3177.204 & 2806.481 \\
\hline 1st day & 4324 & 296 & 235 & 1955 & 3005.100 & 2293.701 \\
\hline 2nd day & 4202 & 283 & 344 & 2026 & 2777.980 & 2019.693 \\
\hline 3rd day & 3707 & 277 & 833 & 2786 & 726.878 & 2659.062 \\
\hline 4th day & 3654 & 267 & 376 & 2758 & 810.688 & 2324.605 \\
\hline
\end{tabular}

\section{Conclusion}

The methodology for analyzing the change in the amount of earthwork has been presented by comparing the design drawing and the measured topography by this research. It has been shown that the change in the amount of earthwork by each location may be seen visually through the application of creating the three-dimensional Analysis Cell. The result of test bed application shows changes of amount of earthwork at work site. The result presents that the amount of cutting and banking identified in the initial stage is decreased gradually as the work progressed. Also, this paper shows that the work sites are changed into the site planned in the design drawing using the Analysis Cell. In this research, the developed system was applied during earthwork period, not for whole earthwork periods.

\section{Acknowledgements}

The current study is supported by research funding (10067705) from the Manufacturing-based Industrial Core Technology Development Project by the Ministry of Trade, Industry and Energy.

\section{References}

[1] S. Kim, J. Park, Analysis of Accuracy and Productivity of Terrestrial Laser Scanner for Earthwork, Journal of the Korea Contents Association, 15(10), 587-596.

[2] D. Lee, S. Kim, J. Park, S. Kwon, Generation of 3D Terrain Map using Cell Deviation Algorithm for Earthwork, Procedia Engineering, 196 (2017) 436-440. 